В.А. Міськів, О.Я. Жураківська, Т.В. Князевич-Чорна, У.М. Дутчак, Я.І. Клипич, М.О. Кулинич-Міськів, В.М. Жураківський, О.Р. Іванців

\title{
МОРФОФУНКЦІОНАЛЬНА ОРГАНІЗАЦІЯ ПАНКРЕАТИЧНИХ ОСТРІВЦІВ ЩУРІВ 24-МІСЯЧНОГО ВІКУ ТА ЇХ ПЕРЕБУДОВА НА 56-ТУ ДОБУ РОЗВИТКУ ЕКСПЕРИМЕНТАЛЬНОГО ЦУКРОВОГО ДІАБЕТУ
}

ДВНЗ «Івано-Франківський національний медичний університет»

Резюме. Зміни в будові панкреатичних острівців (ПО) щурів 24-місячного віку на 56-ту добу розвитку експериментального цукрового діабету характеризуються зменшенням загальної кількості клітин у складі ПО на $36 \%$ та становить $83,1 \pm 2,31$ на 0,1 мм $^{2}$ ПО. В основному це відбувається за рахунок В-клітин, кіль-

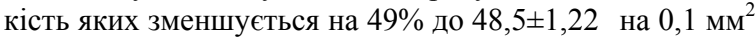
ПО. Зміни гемомікроциркуляторного русла проявля-

Вступ. Про старіння організму ми частіше всього судимо по прояву тих чи інших ознак. 3 фізіологічної точки зору найбільш універсальним проявом старіння організму є зниження здатності організму до адаптації і збільшення ймовірності розвитку патології.

Сьогодні на цукровий діабет (ЦД) страждають 200 млн мешканців Землі. Кожну хвилину у світі від діабету помирає шість людей, а загальні показники смертності значно перевищують такі показники від усіх інфекційних захворювань, включаючи СНІД. Рання інвалідизація і смертність хворих на цукровий діабет зумовлені наявністю специфічних ускладнень - мікроангіопатій (нефропатій, ретинопатій), макроангіопатій (інфаркт міокарда, інсульт, гангрена нижніх кінцівок) і нейропатій. ВООЗ визнала ЦД неінфекційною епідемією 21-го століття, адже в економічно розвинених країнах світу хворих на ЦД 4-6 \% населення. За прогнозами ВООЗ, до 2030 року їх кількість у світі може сягнути 552 млн. Тож ЦД визнано пріоритетом для національних систем охорони здоров'я всіх без винятку країн світу $[5,7]$.

У доступній нам літературі дані про будову панкреатичних острівців (ПО) підшлункової залози (ПЗ) недостатні і часто суперечливі, а порушення функції їх і $є$ причиною виникнення ЦД I типу $[2,6]$.

Мета дослідження. Встановити особливості будови острівцевого апарату підшлункової залози щурів 24-місячного віку та їх перебудови на 56-ту добу розвитку експериментального цукрового діабету.

Матеріал і методи. Робота виконана на 20 білих щурах - самцях лінії Wistar масою 340-420 г 24-місячного віку, що утримувались у стандартних умовах віварію. Для проведення експерименту тварин розподілено на дві групи: перша - інтактна (6 тварин), друга - експериментальна (14 тварин), у яких моделювали експериментальний ються спазмом артеріальної частини, та дилатацією венозної його складової. Пристосувальні реакції характеризувалися функціональною перебудовою клітинних елементів для забезпечення потреб організму в інсуліні.

Ключові слова: підшлункова залоза, гемомікроциркуляторне русло, панкреатичний острівець.

ЦД $[1,4]$ із дослідженням структури та ланок гемомікроциркуляторного русла (ГМЦР) ПО на 56-ту добу експерименту, із них чотири тварини послужили контролем.

Ультраструктурні особливості ПО вивчали під електронним мікроскопом ПЭМ-125 К з прискорюючою напругою 75 кВ. Мікрофотографування препаратів здійснювали на тринокулярному мікроскопі МС 300 (ТХР) з підключеною Digital camera for microscope DCM 900 за допомогою програмного забезпечення Scope Photo.

Морфометрію здійснювали на мікропрепаратах за допомогою програми “Bio Vision 4" в автоматичному або ручному режимі з урахуванням збільшень об'єктів. Структурні зміни на кожному етапі дослідження аналізували в 50 полях зору на площі 0,1 мм $^{2}$ ПО. Отримані дані оцінювали за параметричними та непараметричними статистичними методами.

Результати дослідження та їх обговорення. Встановлено, що ендокринна частина підшлункової залози 24-місячних щурів-самців лінії Вістар представлена ПО, які утворюються скупченням клітин, оточених тонкими прошарками сполучної тканини, що відмежовують їх від екзокринної частини залози. Такі острівці мають переважно овальну або округлу форму та нерівні контури, середня кількість ПО на 1 мм $^{2}$ паренхіми складає $(9,98 \pm 0,35)$, а їх діаметр у тварин цієї вікової групи дорівнює $(96,9 \pm 2,23)$ мкм, площа складає $(11867,84 \pm 658,25)$ мкм $^{2}$.

ПО складаються 3 ендокринних клітин, які на гістологічних препаратах виглядають світлими на тлі темної екзокринної паренхіми. У цитоплазмі ендокринних клітин $є$ добре розвинений білок-синтезуючий апарат, до складу якого входять: комплекс Гольджі, гранулярна ендоплазматична сітка та секреторні гранули. За властивостями останніх ендокринні клітини поділяють на чотири основних різновиди: В-клітини, Аклітини, Д-клітини, РР-клітини. 
Основну масу ПО у щурів цього віку складають В-клітини, яких нараховується $(94,6 \pm 1,68)$ на

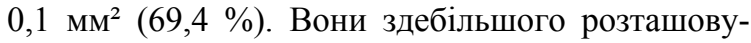
ються у центрі ПО, оточуючи по ходу кровоносні судини. Ці клітини мають полігональну форму і $є$ більш темними порівняно 3 іншими ендокриноцитами (рис. 1).

На ультраструктурному рівні в цитоплазмі В-клітин містяться численні секреторні гранули (СГ), які складаються 3 помірної електроннооптичної щільності матриксу, мембрани та широкого світлого підмембранного обідка. Крім того, матрикс гранули розміщений дещо ексцентричHо.

А-клітини становлять $14,25 \%$ від загальної кількості ендокринних клітин ПО $(18,6 \pm 0,41)$ на

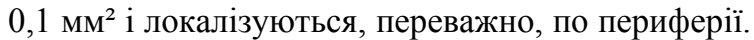
Розміри їх менші, ніж у В-клітин, а ядра бідніші на гетерохроматин. На ультраструктурному рівні в А-клітинах спостерігаються ознаки вікових дистрофічних змін, які характеризуються каріорексисом, вакуолізацією цитоплазми, збільшенням кількості лізосом та аутофагосом, ліпідних крапель і мультивезикулярних тілець.

Д-клітин в острівцях щурів 24-місячного віку нараховується $(7,4 \pm 0,24)$ на 0,1 мм $^{2}$, вони мають зірчасту форму та розміщуються, переважно, на периферії острівця.

РР-клітини мають полігональну форму, розміщуються, переважно, на периферії острівця поміж А-клітинами і мають добре розвинену гранулярну ендоплазматичну сітку та дрібні СГ, розташовані вздовж плазмолеми. Середня кількість цих клітин у ПО є незначною.

Кровопостачання ПО ПЗ щурів здійснюється iз спільних з екзокринною частиною джерел. Артеріоли із середнім значенням діаметра $(20,5 \pm 0,29)$ мкм беруть початок від артерій і розташовуються в прошарках сполучної тканини навколо острівців. Розгалужуючись, вони формують прекапіляри. Вивчаючи серійні напівтонкі зрізи ПО ПЗ щурів 24-місячного віку, ми відзначили, що судини, за морфологічними ознаками віднесені нами до прекапілярів, формують відкриті та закриті петлі, які оточують острівці і да-

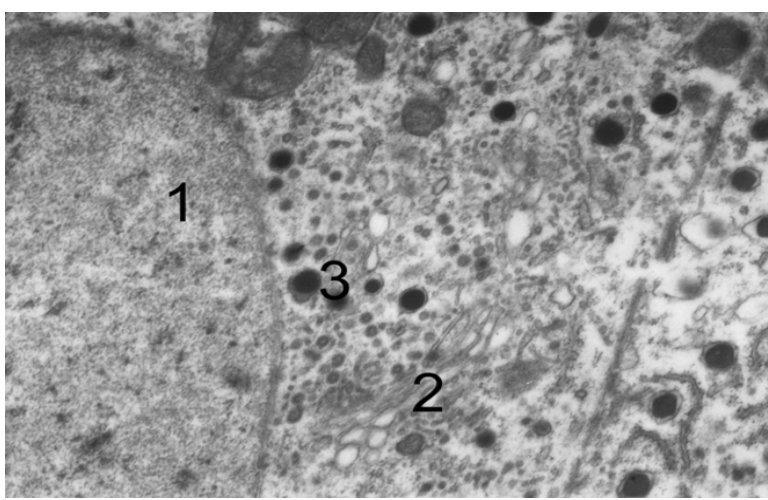

Рис. 1. Субмікроскопічний стан В-клітини панкреатичного острівця у інтактної тварини 24-місячного віку. Зб. x 16000: 1 - ядро, 2 - комплекс Гольджі, 3 - секреторні гранули ють початок капілярам, які лежать поміж ендокриноцитами, анастомозують між собою і утворюють капілярну сітку.

Просвіт прекапілярів є нерівномірним, а середній діаметр складає $(9,2 \pm 0,15)$ мкм. Діаметр капілярів дорівнює $(4,9 \pm 0,52)$ мкм. Капіляри, зливаючись, формують посткапіляри діаметром $(11,6 \pm 0,15)$ мкм, які виходять 3-поміж ендокриноцитів i, об'єднавшись, утворюють венули діаметром $(32,6 \pm 0,40)$ мкм, що розташовуються поряд 3 артеріолами у прошарках сполучної тканини навколо панкреатичних острівців. Нами встановлений кореляційний зв'язок між площею ПО та кількістю судин на 0,1 мм² $^{2}$ ï площі $\mathrm{r}_{\mathrm{s}}=0,9$; $\mathrm{p}=0,037$. Капіляри ПО відносяться до вісцерального типу і вистеляються фенестрованими ендотеліоцитами, які лежать на нерівномірної товщини базальній мембрані. Їх люменальна поверхня формує нечисленні широкі випирання в просвіт судин (рис. 2).

До капілярів прилягають секреторні компартменти ендокриноцитів, що містять велику кількість гранул, спостерігаються ознаки екзоцитозу.

На 56-ту добу після моделювання експериментального ЦД кількість клітин, що утворюють острівці, становить $(83,1 \pm 2,31)(\mathrm{p}<0,05)$. Середня

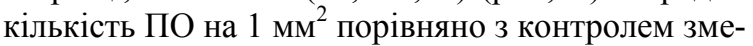
ншується майже в сім разів i становить $(1,14 \pm 0,24)$, зменшується i площа ПО до $(4939,76 \pm 386,45)$ мкм $^{2}(\mathrm{p}<0,005)$.

Серед ендокриноцитів відносно нормальний морфофункціональний стан мають А-клітини, в яких гранули нормального розміру і будови, рівномірно розташовуються по всій цитоплазмі. Ядро розміщене ексцентрично, конденсований хроматин локалізується біля внутрішньої поверхні каріолеми. Ядерця, переважно два, розміщуються на периферії.

Кількість В-клітин зменшується на 49 \% і становить $(48,5 \pm 1,22) \quad(\mathrm{p}<0,05)$. Ядро В-клітин має неправильну форму, зовнішня ядерна мембрана не виявляється, конденсований хроматин нечітко переходить у деконденсований, кількість його більша, ніж у інтактній групі, перинуклеарний простір представлений електроннощільною

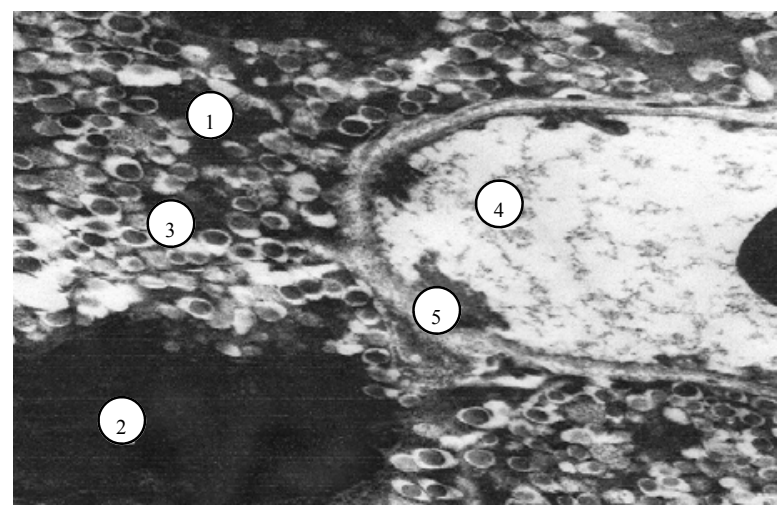

Рис. 2. Ультраструктура капіляра фенестрованого типу в складі острівця підшлункової залози щура 24-місячного віку. Зб. х 8000: 1 - В-клітина; 2 - ядро; 3 - секреторні гранули; 4 - гемокапіляр фенестрованого типу; 5 - вирости люменальної плазмолеми ендотеліоцита 


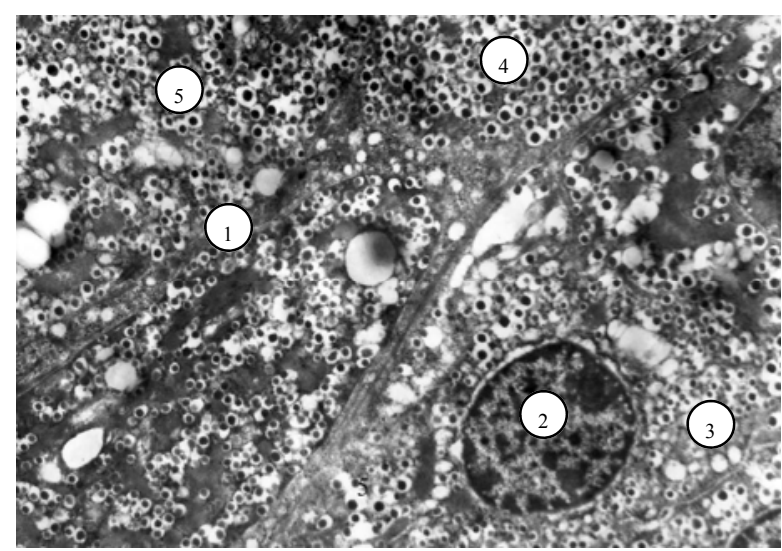

Рис. 3. Ультраструктура панкреатичного острівця 24місячного щура на 56-ту добу після моделювання стрептозотоцинового ЦД. Зб. х 8000: 1 - контакт двох ендокриноцитів; 2 - ядро В-клітини; 3 - вакуолі; 4 - СГ Втипу; 5 - злиття СГ

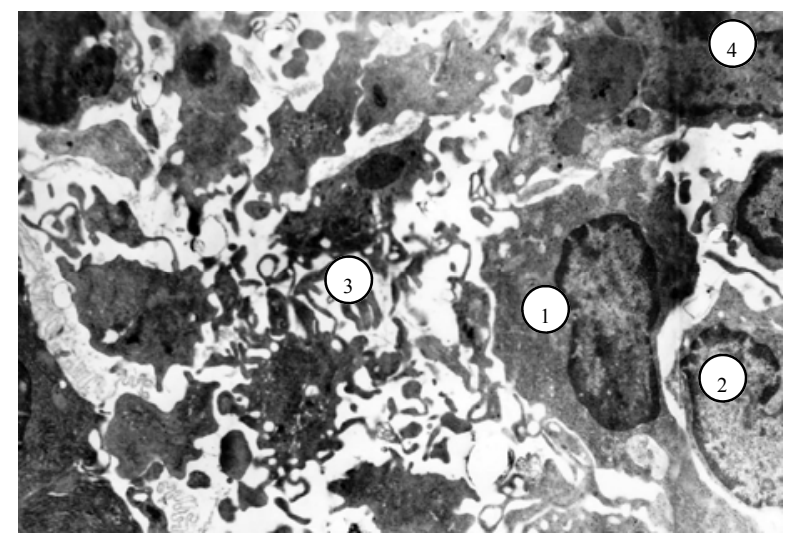

Рис. 5. Субмікроскопічна будова лімфоцитів і макрофагів у періінсулярній сполучній тканині панкреатичного острівця щура 24-місячного віку на 56-ту добу після моделювання стрептозотоцинового ЦД. Зб. х 4000: 1 лімфоцит; 2 - моноцит; 3 - цитоплазматичні вирости макрофага; 4 - макрофаг

смужкою цитоплазми. Секреторні гранули різної форми, хаотично розсіяні по всій цитоплазмі, подекуди утворюють скупчення. Інколи спостерігається крайове стояння секреторних гранул, які формують «ланцюжки» і виділяють вміст у розширені міжклітинні щілини. Органели в цитоплазмі В-клітин майже не визначаються.

Мембранні органели В-клітин руйнуються і заміщуються вакуолями (рис. 3).

У цей термін зменшується просвіт артеріол та досягає $(16,8 \pm 0,18)$ мкм². $^{2}$.

Артеріоли і венули періінсулярної зони зберігають основні структурні компоненти стінки. Однак товщина оболонок збільшується, визначаються ділянки десквамації ендотеліоцитів і деструктивні зміни в міоцитах артеріол, пре-, посткапілярів і венул, у цих місцях накопичуються елементи сполучної тканини (фібробласти і колагенові волокна). Стінка капілярів потовщується за рахунок збільшення товщини ендотеліоцитів і базальної мембрани. Окремі ендотеліоцити руйнуються, а їх цитоплазма виявляється в просвіті капілярів (рис. 4).

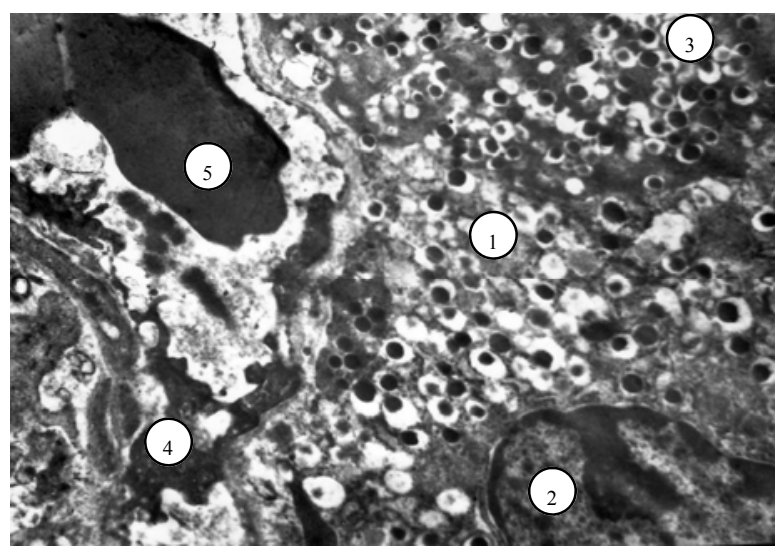

Рис. 4. Ультраструктура панкреатичного острівця щура 24-місячного віку на 56-ту добу після моделювання стрептозотоцинового ЦД. Зб. х 9600: 1 - Вендокриноцит 3 «темною» цитоплазмою; 2 - ядро Вклітини; 3 - цитоплазма А-клітини; 4 - цитоплазма ендотеліоцита; 5 - еритроцит

У періінсулярній сполучній тканині навколо кровоносних судин розміщується велика кількість макрофагів, тканинних базофілів та лімфоцитів. Поверхня макрофагів вкрита цитоплазматичними виростами, у деяких визначається фагоцитований матеріал загиблих клітин (рис. 5).

\section{Висновок}

Зміни в будові панкреатичних острівців на 56-ту добу перебігу експериментального цукрового діабету характеризується зменшенням площі та кількості острівців за рахунок втрати В-клітин. Зміни гемомікроциркуляторного русла проявляються спазмом артеріальної частини та дилатацією венозної його складової.

Перспектива подальших досліджень. Вікові особливості перебігу цукрового діабету потребують комплексного підходу. Тому в наших подальших дослідженнях намагатимемось дослідити реакцію панкреатичних острівців на перебіг експериментального діабету в інших онтогенетичних групах. Крім того, передбачається вивчення острівцевого апарату підшлункової залози при використанні фармакологічної і нефармакологічної корекції.

\section{Література}

1. А.с. на раціоналізаторську пропозицію. Спосіб моделювання цукрового діабету в експерименті / В.А. Левицький, О.Я. Жураківська, В.А. Міськів. - № 1/2585; подано15.01.09; визн. рац. 12.02.09.

2. Боровкова О. С. Питання патогенезу діабетичних ангіопатій / О.С. Боровкова, А. Г. Іфтодій // Бук. мед. вісник. - 2006. - Т. 10, № 2. - С. 132-135.

3. Гагарин В.И. Сахарный диабет и его поздние осложнения / В.И. Гагарин, Л.А. Сыдыкова // Междунар. ж. прикладных и фундаментальных исследований. 2010. - № 11. - С. 95-96.

4. Пат. № 62966. Україна, МПК 51 А 61 В 10/00. Спосіб моделювання цукрового діабету 1-го типу у тварин різного віку / В.А. Левицький, О.Я. Жураківська, В.А. Міськів, Л.М. Заяць, Р.Б. Петрів, Ю.М. Якимів, Б.М. Кіщук, Р.З. Гнатюк; заявка № u 201101566 ; заявл. 11.02.2011; опубл. 20.09.2011. Бюл. № 18. - 6 с. 
5. Тронько М.Д. Епідеміологія цукрового діабету в Україні / М.Д. Тронько, А.Д. Чернобров // Здоров'я України. - 2005. - № 18. - С. 15

6. Inge A. M. van den Oever Endothelial Dysfunction, Inflammation, and Apoptosis in Diabetes Mellitus / Inge A. M. van den Oever, Hennie G. Raterman, Mike T. Nurmohamed// Mediators of Inflammation. - 2010. - № 2010. P. 115-130.
7. Peschke E. "Classical" and "new" diabetogenscomparison of their effects on isolated rat pancreatic islets in vitro / E. Peschke // Cell Mol Life Sci. - 2007. - № 57 (1). - P. 156-164.

8. Screening for associated autoimmunity in type 1 diabetes mellitus with respect to diabetes control / M. Prázny, J. Škrha, Z. Limanová [et al.] // Physiol. Res. - 2005. № 54. - P. 41-48.

\section{МОРФОФУНКЦИОНАЛЬНАЯ ОРГАНИЗАЦИЯ ПАНКРЕАТИЧЕСКИХ ОСТРОВКОВ КРЫС 24-МЕСЯЧНОГО ВОЗРАСТА И ИХ ПЕРЕСТРОЙКА НА 56-ЫЕ СУТКИ РАЗВИТИЯ ЭКСПЕРИМЕНТАЛЬНОГО САХАРНОГО ДИАБЕТА}

\section{В.А. Миськив, О.Я. Жураковская, Т.В. Князевич-Чорна, У.М. Дутчак, Я.И. Клипич, М.О. Кулинич-Миськив, В.Н. Жураковский, О.Р. Иванцив}

Резюме. Изменения в строении панкреатических островков (ПО) крыс 24-месячного возраста на 56-ые сутки развития экспериментального сахарного диабета характеризуются уменьшением общего количества клеток в составе ПО на $36 \%$ и составляет $83,1 \pm 2,31$ на 0,1 мм $^{2}$ ПО, в основном это происходит за счет В-клеток, количество кото-

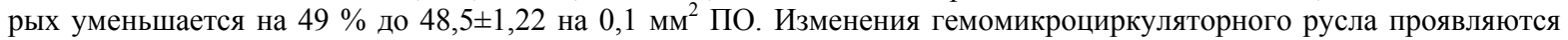
спазмом артериальной части и дилатацией венозной его составляющей. Приспособительные реакции характеризовались функциональной перестройкой клеточных элементов для обеспечения потребностей организма в инсулине.

Ключевые слова: поджелудочная железа, гемомикроциркуляторное русло, панкреатический островок.

\section{MORPHOFUNCTIONAL ORGANIZATION OF PANCREATIC ISLETS IN 24-MONTH-OLD RATS AND THEIR ALTERATIONS ON THE $56^{\text {TH }}$ DAY OF EXPERIMENTAL DIABETES}

\section{V.A. Miskiv, O.Y. Zhurakivska, T.V. Kniazevych-Chorna, U.M. Dutchak, Y.I. Klypych, M.O. Kulynych-Miskiv, V.M. Zhurakivskyi, O.R. Ivantsiv}

Absstract. Changes in the structure of pancreatic islets (PI) in 24-month-old rats on the $56^{\text {th }}$ day of experimental diabetes are characterized by a reduction of total number of cells in PI by $36 \%$ and is $83,1 \pm 2,31$ on $0,1 \mathrm{~mm}^{2}$ of PI, it is primarily due to B-cells, whose number decreases by $49 \%$ to $48,5 \pm 1,22$ on $0,1 \mathrm{~mm}^{2} 2$ of PI. Changes in the microcirculatory blood stream result in spasms of the arterial part and dilatation of its venous component. The adaptive reactions are characterized by a functional alteration of cellular elements to provide the body's need for insulin.

Key words: pancreas, microcirculatory blood stream, pancreatic islet.

SHEI "National Medical University" (Ivano-Frankivsk) 